\title{
INTEGRATION OF STOCK MARKETS OF RUSSIA AND SOUTHEAST ASIA
}
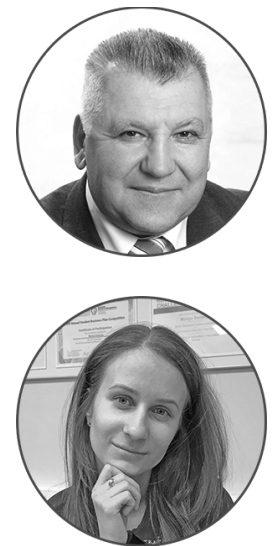

\section{Article history:}

Received 17 January 2018

Received in revised form

16 May 2018

Accepted 4 June 2018

Translated 29 August 2018

Available online 28 September 2018

JEL classification: E44, F36, G14, G15, G23

Keywords: Southeast Asian countries, stock market, comparative analysis, listing, unification

\author{
Petr V.AKININ \\ North Caucasian Federal University (NCFU), Stavropol, Russian Federation \\ akinin_pv@mail.ru \\ http://orcid.org/0000-0003-1317-4926 \\ Corresponding author \\ Yuliya O. BOLDAREVA \\ North Caucasian Federal University (NCFU), Stavropol, Russian Federation \\ Boldareva.julya2012@yandex.ru \\ ORCID: not available
}

The editor-in-charge of this article was Irina M. Vechkanova

Authorized translation by Irina M. Vechkanova

The increasing role of stock markets is an inseparable aspect of the contemporary economy, having a global significance as part of financial markets. The financial world and community tends to become financially fragmented, thus hindering international relationships. The EuroAtlantic region is more and more likely to lose their

${ }^{\dagger}$ For the source article, please refer to: Акинин П.В., Болдарева Ю.О. Интеграция фондовых площадок России и стран ЮгоВосточной Азии. Региональная экономика: теория и практика. 2018. T. 16. № 7. C. 1192-1205. URL: https://doi.org/10.24891/re.16.7.1192 economic hegemony. This will clear new horizons to would-be global actors.

Observing geopolitical developments, the powerthat-be and business community are primarily conscious of the revitalizing economic activity in Siberia and Far East, international ties with China, India, Japan, South Korea and other eastern countries [1-4].

The connection of the Russian and Asia trade platforms is one of the points to diversify the Russian 
economy. We analyzed legislative documents governing the Russian and Asian stock markets in terms of their consistency [5-10].

Nowadays the Russian stock exchanges are presented by 10 trading platforms. However, the genuine trade in securities is concentrated on four stock exchanges. Moscow Exchange is the main trading venue of Russia. It was founded by merging The Moscow Interbank Currency Exchange (MICEX) Group and Russian Trading System (RTS) Group in December $2011^{1}$.

The exchange mainly forms prices in the financial market by concentrating liquidity and promulgating strict trading rules $^{2}$. As seen in international practices, exchanges serve as a versatile method to obtain access to a variety of investors, including institutional ones, which are entitled to put their money into financial instruments in accordance with strict requirements (Table 1) 3, 4, 6 .

However, if the issuing entity is restructured, it is subject to the rule requiring to prepare and publish its audited (consolidated) financial statements under IFRS/U.S. GAAP starting from the year when the restructuring was completed. If the restructuring is completed after October 1 , it shall publish financial statements starting from the year following the one when the restructuring took place. Furthermore, as for bonds issued by the Russian entities, the requirement is also applicable to the guarantor in case of the issuer's restructuring.

\footnotetext{
${ }^{1}$ Moscow Exchange. URL: https://www.moex.com/en/

${ }^{2}$ Popovich V., Blackwell T., Dubovitskaya E. Rukovodstvo dlya emitenta: podgotovka k IPO [Issuer's Guide: Preparing for an IPO]. URL: https://ipoguide.moex.com/section-2-1.html (In Russ.)

${ }^{3}$ Akuev M., Murygin A., Belyasov I., Potok L. Rukovodstvo dlya emitenta: podgotovka k IPO [Issuer's Guide: Preparing for an IPO]. URL: https://ipoguide.moex.com/section-3.html (In Russ.)

${ }^{4}$ Civil Code of the Russian Federation.

URL: https://www.consultant.ru/document/cons_doc_LAW_5142/ (In Russ.)

${ }^{5}$ Federal Law On Organized Bidding of November 21, 2011 № 325-Ф3. URL: https://www.consultant.ru/document/cons_doc_LAW_121888/ (In Russ.)

${ }^{6}$ Order of the RF Ministry of Finance On the Procedures for the Admission of Securities to Organized Bidding of July 30, 2013 № 13-62/п3-н. URL:

https://www.consultant.ru/document/cons_doc_LAW_197599/ (In Russ.)
}

The metrics below are important on a stock exchange. They are measured for periods indicated in Table 1: $\mathrm{PnL}_{\mathrm{e}}$ is the financial result (profit or loss) of the issuer as per its annual (consolidated) financial statements under IFRS/U.S. GAAP for the last cut-off reporting year. $\mathrm{PnL}_{\mathrm{g}}$ is the financial result (profit or loss) of the guarantor as per its annual (consolidated) financial statements for the last cut-of reporting year.

If the issuer and guarantor pertain to the same group, $\mathrm{GPn}_{\mathrm{L}}$ is equal to profit (loss) as per the audited consolidated financial statements prepared by the group under IFRS/U.S. GAAP for the last cut-off reporting year. GPn $\mathrm{n}_{\mathrm{L}}$ is the sum of the two indicators. If $\mathrm{PnL}_{\mathrm{e}}$ is positive, $\mathrm{GPn}_{\mathrm{L}}$ is equal to $P n L_{e}$.

The stock market of the Asian countries is concentrated on two major trading venues. It is noteworthy that the exchanges are on the World Top-7 list of the best exchanges, going fifth and sixth respectively. Both trading venues offer issuers certain listing terms (Table 2, 3).

We believe it is reasonable to explain what requirements resource supplying companies have to meet operating on the Hong Kong Stock Exchange.

A resource supplying company is a business, which primarily conducts geological surveys as its core activity in order to produce mineral resources, including minerals, oil, gas and solid fuels. The core activity can be qualified as such if it involves more than 25 percent of corporate assets, gross revenue or operating expenses.

Listing requirements are the same as for the other companies. However, would-be issuers seeking to be listed on the principal trading venue may not be subject to two-year profit, capitalization and commercial activity requirements, if the Hong Kong Stock Exchange gets assured that the board of directors or top executives collectively have appropriate experience in geological survey or mining. Members of the board of directors and top executives should have relevant professional experience in the sector of at least five years.

The company should posses the estimated amount of natural resources and conditional resources, 
which encompass a considerable and sufficient percentage of valuable components, being measured in accordance with one of the globally accepted reporting standards and corroborated with the report of independent and credible appraisers dealing with natural resource cases.

The company should hold sufficient working capital accounting for 125 percent of its current financial needs as estimated for the following year.

The resource producing company, which has not started the mining process yet, must disclose its mining commencement plans, indicating approximate dates and costs, which shall be verified at least with preliminary surveys and confirmed with the independent and credible appraiser's report.

The listing prospectus shall inform of social and environmental aspects, if they are material ${ }^{7}$.

Shares in the Shanghai Stock Exchange ${ }^{8}$ are split into two segments:

- A-Shares, which are available for foreign investment only under the Qualified Foreign Institutional Investor (QFII) program and denominated only in the yuan;

- B-Shares, which are available for all foreign partners and investment and denominated in USD.

Unlike the Hong Kong Stock Exchange, the Shanghai Stock Exchange is not fully accessible for foreign investors and controlled by the China Securities Regulatory Commission - CSRC. Whereas Hong Kong is supposed to attract foreign capital, Shanghai retains and develops the domestic one.
Overviewing the requirements to trading mechanisms of each trade venue, we analyzed their concordance, regulation and interpretation on each of them. The findings are presented in Table 4.

Comparing the existing requirements, we detected some mismatch of several aspects, i.e. capitalization and debt, internal control system, forecast of working capital adequacy, profit forecast.

Having scrutinized and specified the mismatch, we managed to outline the draft road map for integrating the Russian and Southeastern stock exchanges (Table 5).

As the analysis proves, the discordance is not critical and conceptually important, without seriously hampering its elimination. According to our estimates, it may take from two to three years to reverse the discordance and make respective amendments to the legislative and regulatory documents. As part of the research, we revealed dominating aspects of the current global and national trends in the development. In the nearest future, stock markets are expected to demonstrate different development trends, including the Russian ones.

Developments in infrastructure, talent, resources will change sentiments about the Asian (eastern) countries. Turn to the east used to be just a phrase. The integration process cannot be left unnoticed. Further goals and development strategies should be clarified. The proposed research and findings will contribute to the development of the Russian economy during the difficult turbulent time.

\footnotetext{
${ }^{7}$ Rynki kapitala v 2025: Budushchee fondovykh rynkov [Capital Markets in 2025: The Future of Equity Capital Markets]. URL: https://www.pwc.ru/en/capitalmarkets/publications/assets/capital_markets_in_2025_rus.pdf (In Russ.)

${ }^{8}$ Osobennosti fondovogo rynka Kitaya [Distinctions of the Chinese stock market]. URL: http://goldok.ru/rynki-i-birzhi/osobennostifondovogo-rynka-kitaya.html (In Russ.)
}

Please cite this article as: Akinin P.V., Boldareva Yu.0. Integration of Stock Markets of Russia and Southeast Asia. Digest Finance, 2018, vol. 23, iss. 3, pp. 327-335. 
Table 1

Going-public conditions in the Russian Federation: the total market value of the issuer's float and the shares: Listing on the Moscow Exchange

\begin{tabular}{|c|c|c|}
\hline Requirements & Level 1 & Level 2 \\
\hline \multicolumn{3}{|c|}{ Stocks issued by the Russian companies } \\
\hline \multirow[t]{2}{*}{ Common stocks } & $\begin{array}{l}\text { At least RUB } 3 \text { billion and at least } 10 \text { percent of total } \\
\text { common stocks issued, respectively (if the market } \\
\text { capitalization of the issuer exceeds RUB } 60 \text { billion) }\end{array}$ & $\begin{array}{l}\text { At least RUB } 1 \text { billion and at least } 10 \text { percent of all } \\
\text { common stocks issued, respectively }\end{array}$ \\
\hline & $\begin{array}{l}\text { At least RUB } 3 \text { billion and at least FF of total common stocks } \\
\text { issued, respectively (if the market capitalization of the issuer } \\
\text { is RUB } 60 \text { billion or less); } \\
F F=(0.25789-0.00263 \cdot \text { Cap }) \cdot 100 \% \text {, } \\
\text { where Cap is the market capitalization of the issuer, } \\
\text { billion RUB }\end{array}$ & \\
\hline Preferred stocks & $\begin{array}{l}\text { At least RUB } 1 \text { billion and at least } 50 \text { percent of total } \\
\text { preferred stocks issued, respectively }\end{array}$ & $\begin{array}{l}\text { At least RUB } 500 \text { million and at least } 50 \text { percent of } \\
\text { total preferred stocks issued, respectively }\end{array}$ \\
\hline $\begin{array}{l}\text { The life period of the issuer or } \\
\text { legal entity underlying } \\
\text { the issuer as a result of its } \\
\text { restructuring, which controls } \\
\text { one or more businesses as per } \\
\text { consolidated financial } \\
\text { statements, on condition that } \\
\text { the business (businesses) } \\
\text { accounts for at least } 50 \text { percent } \\
\text { of total business of the group, } \\
\text { which the issuer pertains to }\end{array}$ & At least three years & At least one year \\
\hline $\begin{array}{l}\text { Preparation and release of } \\
\text { audited (consolidated) financial } \\
\text { statements compiled under } \\
\text { IFRS/U.S. GAAP }\end{array}$ & $\begin{array}{l}\text { For three cut-off years preceding the date when stocks were } \\
\text { admitted to IPO Level } 1\end{array}$ & $\begin{array}{l}\text { For one cut-off year preceding the date when } \\
\text { stocks were admitted to IPO Level } 2\end{array}$ \\
\hline $\begin{array}{l}\text { Compliance with specific } \\
\text { corporate government } \\
\text { requirements }\end{array}$ & Yes & Yes \\
\hline \multicolumn{3}{|c|}{ Bonds issued by the Russian companies } \\
\hline Number of bonds issued & At least RUB 2 billion & At least RUB 500 million \\
\hline Par value of bonds & Below RUB 50 thousand & Below RUB 50 thousand \\
\hline $\begin{array}{l}\text { The life period of the issuer or } \\
\text { guarantor (the requirement is in } \\
\text { applicable if a collateral is } \\
\text { provided, which is at least } \\
\text { worth the amount of bonds } \\
\text { issued) }\end{array}$ & At least three years & At least one year \\
\hline $\begin{array}{l}\text { The issuer's stocks and/or } \\
\text { bonds listed on the Moscow } \\
\text { Exchange (applicable only to } \\
\text { the issue of exchange-traded } \\
\text { bonds) }\end{array}$ & Yes & Yes \\
\hline $\begin{array}{l}\text { Preparation and release of } \\
\text { audited (consolidated) financial } \\
\text { statements of the issuer (and } \\
\text { the guarantor, if applicable) } \\
\text { under IFRS/U.S. GAAP }\end{array}$ & $\begin{array}{l}\text { For the three cut-off years preceding the date when bonds } \\
\text { wee admitted to Level } 1\end{array}$ & $\begin{array}{l}\text { For one cut-off year preceding the date when } \\
\text { bonds were admitted to Level } 2\end{array}$ \\
\hline
\end{tabular}

Please cite this article as: Akinin P.V., Boldareva Yu.O. Integration of Stock Markets of Russia and Southeast Asia. Digest Finance, 2018, 


\begin{tabular}{lll}
\hline No losses & $G P n_{\llcorner}$is positive as per results for the most recent three years & $\begin{array}{l}G P n_{\llcorner} \text {is positive as per results of one year } \\
\text { out of the most recent three years }\end{array}$ \\
\hline No default of the issuer & $\begin{array}{l}\text { No default, or lat least three years passed from the date } \\
\text { when the issuer extinguished the defaulted liabilities }\end{array}$ & $\begin{array}{l}\text { No default, or at least two years passed } \\
\text { from the date when the issuer extinguished } \\
\text { the defaulted liabilities }\end{array}$ \\
\hline $\begin{array}{l}\text { Credit rating of the issuer, } \\
\text { the issue of bonds or the } \\
\text { guarantor }\end{array}$ & Yes & - \\
\hline $\begin{array}{l}\text { Compliance with specific } \\
\text { corporate governance } \\
\text { requirements }\end{array}$ & Yes & - \\
\hline
\end{tabular}

Source: Moscow Exchange. URL: http://www.moex.com

\section{Table 2}

Listing requirements on the main market of the Hong Kong and Shanghai Stock Exchanges

\begin{tabular}{|c|c|c|}
\hline \multirow[t]{9}{*}{ Requirements } & Hong Kong Stock Exchange & Shanghai Stock Exchange \\
\hline & $\begin{array}{l}\text { Information on commercial activities for three most recent } \\
\text { financial years }\end{array}$ & \multirow{4}{*}{$\begin{array}{l}\text { Publicly listed shared shall be more than } 25 \text { percent of total } \\
\text { share capital. Equity is over CNY } 30 \text { million (USD } 4.3 \text { million). } \\
\text { In the case of companies with the share capital exceeding } \\
\text { CNY } 400 \text { million, the ratio of publicly listed shares and total } \\
\text { share capital shall be more than } 15 \text { percent. The company's } \\
\text { operations should be active for more than three years, } \\
\text { generating profit for the three most recent years }\end{array}$} \\
\hline & $\begin{array}{l}\text { The stable and unchanged composition of officers for three } \\
\text { preceding financial years }\end{array}$ & \\
\hline & $\begin{array}{l}\text { The stable and unchanged composition of owners } \\
\text { and controlling persons within at least one financial year } \\
\text { before an IPO }\end{array}$ & \\
\hline & $\begin{array}{l}\text { At least } 25 \text { percent of freely floating shares or 15-25 percent } \\
\text { of shares in case of capitalization exceeding HKD } 10 \text { billion } \\
\text { (about USD } 1.3 \text { billion) }\end{array}$ & \\
\hline & At least 300 shareholders & \multirow{2}{*}{$\begin{array}{l}\text { At least } 300 \text { shareholders. In the case of a holding group, } \\
\text { at least } 1,000 \text { people }\end{array}$} \\
\hline & $\begin{array}{l}\text { Three independent directors, who are not members of } \\
\text { the company's management, including one director certified } \\
\text { in accounting or financial management }\end{array}$ & \\
\hline & Audit committee & $\begin{array}{l}\text { Full disclosure of information in relation to controlling } \\
\text { shareholders }\end{array}$ \\
\hline & $\begin{array}{l}\text { Controlling shareholders or directors are allowed to have } \\
\text { competing entities given they duly disclose respective } \\
\text { information }\end{array}$ & Good and legitimate business \\
\hline
\end{tabular}

Source:Hong Kong Stock Exchange. URL: https://www.hkex.com.hk; Shanghai Stock Exchange; URL: https://www.sse.com.cn

\section{Table 3}

Revenue and market capitalization requirements on the main trading venue of the Hong Kong Stock Exchange

\begin{tabular}{|c|c|c|c|}
\hline \multirow[t]{4}{*}{ Requirements } & Profit and cash flows & Market capitalization & Revenue \\
\hline & $\begin{array}{l}\text { Profit of at least HKD } 20 \text { million (about USD } 2.6 \text { million) } \\
\text { for the recent financial year }\end{array}$ & $\begin{array}{l}\text { At least HKD } 2 \text { billion } \\
\text { (about USD } 256 \text { million) }\end{array}$ & $\begin{array}{l}\text { At least HKD } 500 \text { million } \\
\text { (about USD } 64 \text { million) for } \\
\text { the previous financial year }\end{array}$ \\
\hline & $\begin{array}{l}\text { Profit of at least HKD } 30 \text { million (about USD } 3.8 \text { million) } \\
\text { for two most recent financial years }\end{array}$ & \multirow[t]{2}{*}{$\begin{array}{l}\text { At least HKD } 4 \text { billion } \\
\text { (about USD } 513 \text { million) }\end{array}$} & \multirow{2}{*}{$\begin{array}{l}\text { At least HKD } 500 \text { million } \\
\text { (about USD } 64 \text { million) } \\
\text { for the most recent } \\
\text { financial year }\end{array}$} \\
\hline & $\begin{array}{l}\text { Operating profit of at least HKD } 100 \text { million (about USD } \\
13 \text { million) for three most recent financial years totally }\end{array}$ & & \\
\hline
\end{tabular}

Source: Hong Kong Stock Exchange. URL: https://www.hkex.com.hk

Please cite this article as: Akinin P.V., Boldareva Yu.0. Integration of Stock Markets of Russia and Southeast Asia. Digest Finance, 2018, vol. 23, iss. 3, pp. 327-335. 


\section{Table 4}

Comparison of the exchange trading mechanisms of the Russian and Asian stock markets

\begin{tabular}{|c|c|c|}
\hline Requirements & Hong Kong Stock Exchange & Shanghai Stock Exchange \\
\hline $\begin{array}{l}\text { Information on commercial activities for three financial } \\
\text { years }\end{array}$ & Identical requirements & Identical requirements \\
\hline $\begin{array}{l}\text { The stable and unchanged composition of } \\
\text { management within three most recent financial years }\end{array}$ & Identical requirements & Identical requirements \\
\hline $\begin{array}{l}\text { The stable and unchanged composition of owners } \\
\text { and those charged with governance }\end{array}$ & $\begin{array}{l}\text { The stable composition of owners and those } \\
\text { charged with governance within the period of } \\
\text { at least one financial year, which was audited } \\
\text { immediately before the IPO }\end{array}$ & No specific requirements \\
\hline $\begin{array}{l}\text { The minimum percentage of freely floating shares is } \\
\text { about or less than } 25 \text { percent in case of high market } \\
\text { capitalization }\end{array}$ & Identical requirements & Identical requirements \\
\hline $\begin{array}{l}\text { Three independent directors, who are not members } \\
\text { of the company's management, including one director } \\
\text { certified in accounting or financial management }\end{array}$ & Identical requirements & Identical requirements \\
\hline Audit Committee & Identical requirements & Identical requirements \\
\hline $\begin{array}{l}\text { Controlling shareholders or directors are allowed } \\
\text { to have competing entities given they duly disclose } \\
\text { respective information }\end{array}$ & Identical requirements & Identical requirements \\
\hline Jurisdiction & $\begin{array}{l}\text { IPO is permitted to companies registered } \\
\text { in one of } 26 \text { jurisdictions }\end{array}$ & $\begin{array}{l}\text { Qualified Foreign Institutional Investors } \\
\text { (QFII) }\end{array}$ \\
\hline Sponsor to be appointed & Required & Required \\
\hline $\begin{array}{l}\text { Auditor's Report: Three years and interim period } \\
\text { under GAAP }\end{array}$ & $\begin{array}{l}\text { Hong Kong Financial reporting Standards } \\
\text { or IFRS }\end{array}$ & $\begin{array}{l}\text { China Securities Regulatory Commission or } \\
\text { IFRS }\end{array}$ \\
\hline Profit estimation & $\begin{array}{l}\text { On a voluntary basis. If the information is } \\
\text { included into the prospectus, the auditor's } \\
\text { report shall be attached }\end{array}$ & No specific requirements \\
\hline $\begin{array}{l}\text { Forecast of working capital adequacy. The Auditor's } \\
\text { Report is usually required }\end{array}$ & $\begin{array}{l}\text { Included into the financial and business } \\
\text { performance analysis }\end{array}$ & $\begin{array}{l}\text { Detailed report included into the } \\
\text { comprehensive report on the financial and } \\
\text { business performance analysis }\end{array}$ \\
\hline Pro-forma financial information & Required, including the Auditor's Report & Required, including the Auditor's Report \\
\hline Capitalization and debt & $\begin{array}{l}\text { The report is required (within an eight week } \\
\text { time before the prospectus is released) }\end{array}$ & $\begin{array}{l}\text { The report is required (within an eight } \\
\text { to ten week time before the prospectus } \\
\text { is released) }\end{array}$ \\
\hline $\begin{array}{l}\text { Comprehensive report on the financial and business } \\
\text { performance analysis }\end{array}$ & No specific requirements & Required \\
\hline Internal controls & $\begin{array}{l}\text { Form-PN 21. The agreed-upon procedures } \\
\text { report of the auditor is usually required }\end{array}$ & $\begin{array}{l}\text { China Securities Regulatory Commission } \\
\text { is responsible for control, requiring } \\
\text { the agreed report issued by the auditor }\end{array}$ \\
\hline Continued & & \\
\hline Requirements & Moscow Exchange & \\
\hline $\begin{array}{l}\text { Information on commercial activities for three } \\
\text { financial years }\end{array}$ & Identical requirements & \\
\hline $\begin{array}{l}\text { The stable and unchanged composition } \\
\text { of management within three most recent financial } \\
\text { years }\end{array}$ & Yes & \\
\hline $\begin{array}{l}\text { The stable and unchanged composition of owners } \\
\text { and those charged with governance }\end{array}$ & \multicolumn{2}{|c|}{$\begin{array}{l}\text { The stable and unchanged composition of owners and those charged with governance within } \\
\text { a period of at least three years, which were subject to auditing immediately before the IPO }\end{array}$} \\
\hline
\end{tabular}

Please cite this article as: Akinin P.V., Boldareva Yu.O. Integration of Stock Markets of Russia and Southeast Asia. Digest Finance, 2018, 


\begin{tabular}{|c|c|}
\hline $\begin{array}{l}\text { The minimum percentage of freely floating shares } \\
\text { is about or less than } 25 \text { percent in case of high } \\
\text { market capitalization }\end{array}$ & Yes \\
\hline $\begin{array}{l}\text { Three independent directors, who are not members } \\
\text { of the company's management, including one } \\
\text { director certified in accounting or financial } \\
\text { management }\end{array}$ & $\begin{array}{l}\text { At least three members on the board of director, one independent director qualified } \\
\text { in the preparation, evaluation and audit of financial statements }\end{array}$ \\
\hline Audit Committee & $\begin{array}{l}\text { Yes, only independent directors. If it is impossible due to objective reasons, the majority } \\
\text { of the Audit Committee members shall be independent directors, with the rest of them being } \\
\text { represented with members of the Board of Directors, without being the sole executive body } \\
\text { and/or members of a collective executive body of the issuer }\end{array}$ \\
\hline $\begin{array}{l}\text { Controlling shareholders or directors are allowed to } \\
\text { have competing entities given they duly disclose } \\
\text { respective information }\end{array}$ & Yes \\
\hline Jurisdiction & $\begin{array}{l}\text { The Procedures for Admission of Securities to Organized Bidding regulates access to IPO. } \\
\text { If the IPO concern any international matters like the place of the issuer's securities outside } \\
\text { Russia, the issuer has to get the permission of the Central Bank of Russia. Placing securities only } \\
\text { in Russia, involving foreign investors, no permission of the Central Bank of Russia } \\
\text { is required }\end{array}$ \\
\hline Sponsor to be appointed & Required \\
\hline $\begin{array}{l}\text { Auditor's Report: Three years and interim period } \\
\text { under GAAP }\end{array}$ & IFRS \\
\hline Profit estimation & Inapplicable \\
\hline $\begin{array}{l}\text { Forecast of working capital adequacy. The Auditor's } \\
\text { Report is usually required }\end{array}$ & No specific requirements \\
\hline Pro-forma financial information & The Auditor's Report shall be included \\
\hline Capitalization and debt & $\begin{array}{l}\text { Figures are given as of the date of the most recent cut-off reporting year and recent cut-off } \\
\text { reporting period before the date of the prospectus approval }\end{array}$ \\
\hline $\begin{array}{l}\text { Comprehensive report on the financial and business } \\
\text { performance analysis }\end{array}$ & $\begin{array}{l}\text { Yes, economic analysis of the issuer's profit/loss is conducted, considering trends in the given } \\
\text { figures }\end{array}$ \\
\hline Internal controls & $\begin{array}{l}\text { There should be detailed and full account of the design of functions responsible for internal } \\
\text { control over the issuer's financial and business performance and their competence } \\
\text { in accordance with the article of association (constituent documents) and internal regulations } \\
\text { of the issuer. } \\
\text { The issuer should inform of the way it manages risks and performs internal control over its } \\
\text { financial and business operations (internal audit), including: } \\
\text { - information on the existence of the Committee for Audit of the Board of Directors } \\
\text { (Supervisory Board), its functions, members and their numbers; } \\
\text { - information on the existence of a dedicated unit (units) for risk management and internal } \\
\text { control (other than the revision commission (revision officer), body (structural unit) controlling } \\
\text { the issuer's financial and business performance, its tasks and functions; } \\
\text { - information on the existence of the issuer's dedicated structural unit (service) for internal } \\
\text { audit, its tasks and functions. } \\
\text { The issuer should describe its policy for risk management and internal control, and state } \\
\text { the existence of its internal regulation governing the prevention of confidential and insider } \\
\text { information misuse }\end{array}$ \\
\hline
\end{tabular}

Source:Authoring

Please cite this article as: Akinin P.V., Boldareva Yu.0. Integration of Stock Markets of Russia and Southeast Asia. Digest Finance, 2018, vol. 23, iss. 3, pp. 327-335. 
Table 5

Measures to ensure the organizational and regulatory concordance of the stock market trading requirements in Russia and Southeast Asian countries: The road map elements

\begin{tabular}{|c|c|c|}
\hline \multirow[t]{2}{*}{ Defaulting requirement } & \multicolumn{2}{|l|}{ IPO Action Plan } \\
\hline & Shanghai Stock Exchange & Hong Kong Stock Exchange \\
\hline Total market value of the issuer & $\begin{array}{l}\text { Increasing total market value of an entity } \\
\text { up to USD } 4.3 \text { billion }\end{array}$ & $\begin{array}{l}\text { Increasing total market value of an entity } \\
\text { up to USD } 26 \text { million }\end{array}$ \\
\hline $\begin{array}{l}\text { The stable composition of owners and } \\
\text { those charged with governance }\end{array}$ & $\begin{array}{l}\text { The aspect is not taken into consideration in case of } \\
\text { IPO }\end{array}$ & Compliance is required \\
\hline Audit Committee & $\begin{array}{l}\text { The audit committee should be made up of } \\
\text { independent directors only. That is, eliminating } \\
\text { circumstances requiring a majority of the Audit } \\
\text { Committee members to be independent directors only, } \\
\text { while the other members may be members of the } \\
\text { Board of Directors, who are not the sole executive } \\
\text { body and/or members of the collective executive body } \\
\text { of the issuer }\end{array}$ & Identical plan \\
\hline Jurisdiction & $\begin{array}{l}\text { The Qualified Foreign Institutional Investor (QFII) } \\
\text { Committee shall be established to purchase A-shares }\end{array}$ & $\begin{array}{l}\text { The procedure for ratifying the Double Tax } \\
\text { Avoidance Agreement }\end{array}$ \\
\hline GAAP & $\begin{array}{l}\text { Allowing the certified auditors from Hong Kong to } \\
\text { access financial statements (Reports and Financial } \\
\text { Statements, Auditor's Report) }\end{array}$ & $\begin{array}{l}\text { China Securities Regulatory Commission shall } \\
\text { be empowered to govern the circulation of } \\
\text { securities }\end{array}$ \\
\hline Internal control & $\begin{array}{l}\text { Amendments shall be made to subparagraph } 5.4 \text { of } \\
\text { the Regulation on Disclosures by Issuers of Securities, } \\
\text { which would comply with Form-PN } 21\end{array}$ & $\begin{array}{l}\text { Amendments shall be made to subparagraph } \\
5.4 \text { of the Regulation on Disclosures by Issuers } \\
\text { of Securities allowing to observe listings } \\
\text { and Initial Public Offering }\end{array}$ \\
\hline Capitalization and debt & $\begin{array}{l}\text { Amendments shall be made to subparagraph } 6.7 \\
\text { Regulation on Disclosures by Issuers of Securities } \\
\text { binding them them to submit the report within eight } \\
\text { weeks before the prospectus is released as part of IPO } \\
\text { on the Asian stock exchanges }\end{array}$ & Identical plan \\
\hline $\begin{array}{l}\text { Forecast of working capital adequacy. } \\
\text { The Auditor's Report is required }\end{array}$ & $\begin{array}{l}\text { Before the Board of Directors makes a decision on } \\
\text { the issue and placement of securities, it is necessary to } \\
\text { forecast the working capital adequacy (performed by } \\
\text { the independent audit) and do it as one } \\
\text { of the mandatory procedures }\end{array}$ & Identical plan \\
\hline
\end{tabular}

Source: Authoring

\section{Acknowledgments}

We are profoundly grateful to Ekaterina A. NESTERENKO, Doctor of Economic Sciences, Professor, Head of the Finance Department of the Saratov Socio-Economic Institute, Branch of the Plekhanov Russian University of Economics, and Aleksandr A. GLADILIN, Candidate of Economic Sciences, Associate Professor of the Finance, Credit and Insurance Department of the Stavropol State Agrarian University, for constructive recommendations on this article.

\section{References}

1. Glaz'ev S.Yu. Bitva za liderstvo v XXI veke. Rossiya, SShA, Kitai. Sem' variantov blizhaishego budushchego: monografiya [The battle for leadership in the 21st century. Russia, USA, China. Seven variants of the nearest future: a monograph]. Moscow, Knizhnyi mir Publ., 2017, 352 p. 
2. Filosofova T., Yangel' A. [Competition or partnership: problems and prospects of business cooperation between China and the ASEAN countries]. Mezhdunarodnaya ekonomika = International Economics, 2012, no. 2, pp. 44-56. (In Russ.)

3. Rastyannikova E.V. BRIKS: pervichnyi sektor ekonomiki v mirovom khozyaistve v nachale XXI veka: monografiya [BRICS: Primary economic sector in the world economy at the beginning of the 21st century: a monograph]. Moscow, Institute of Oriental Studies of the Russian Academy of Sciences Publ., 2016, $272 \mathrm{p}$.

4. Lukin A.V. Rossiya i Kitai: chetyre veka vzaimodeistviya. Istoriya, sovremennoe sostoyanie i perspektivy razvitiya rossiisko-kitaiskikh otnoshenii: monografiya [Russia and China: four centuries of interaction. History, current state and prospects of development of the Russian-Chinese relations: a monograph]. Moscow, Ves' Mir Publ., 2013, 704 p.

5. Glaz'ev S.Yu. [Between Washington and Beijing]. Ekonomicheskie strategii = Economic Strategies, 2015, vol. 17, iss. 1, pp. 6-17. URL: http://www.inesnet.ru/wp-content/mag_archive/2015_01/es2015-01-00616_Sergey_Glaziev.pdf (In Russ.)

6. Makarova A.D. [China's stock market, its exchanges and indices]. Molodoi uchenyi $=$ Young Scientist, 2016, no. 28-5, pp. 484-486. URL: https://moluch.ru/archive/132/37016/ (In Russ.)

7. Glaz'ev S.Yu. [National economy structures in the global economic development]. Ekonomika $i$ matematicheskie metody = Economics and Mathematical Methods, 2016, vol. 52, iss. 2, pp. 3-29. (In Russ.)

8. Egorova N.E., Torzhevskii K.A. [Mathematical models and analysis methods for stock markets and their applying in the Russian environment]. Ekonomika i matematicheskie metody = Economics and Mathematical Methods, 2015, vol. 51, iss. 1, pp. 68-79. (In Russ.)

9. Glaz'ev S.Yu. [Applied results in the theory of world economic structures]. Ekonomika i matematicheskie metody = Economics and Mathematical Methods, 2016, vol. 52, iss. 3, pp. 3-21. (In Russ.)

10. Mirkin Ya.M., Dobashina I.V. [Russian economy: challenges and scenarios of volatile future]. Ekonomicheskaya nauka sovremennoi Rossii = Economics of Contemporary Russia, 2017, no. 3, pp. 22-38. URL: https://www.ecr-journal.ru/jour/article/view/35/35 (In Russ.)

\section{Conflict-of-interest notification}

We, the authors of this article, bindingly and explicitly declare of the partial and total lack of actual or potential conflict of interest with any other third party whatsoever, which may arise as a result of the publication of this article. This statement relates to the study, data collection and interpretation, writing and preparation of the article, and the decision to submit the manuscript for publication. 